\title{
Protocols for the Extraction of High-quality RNA from Pineapple Tiller, Flower, Inflorescence, and Fruits
}

\author{
Khairul Nizam Sehat, S. Vijay Kumar and Noor Hydayaty Md Yusuf* \\ Biotechnology Research Institute, Universiti Malaysia Sabah, Jln UMS, 88400 Kota Kinabalu, Sabah, Malaysia
}

\begin{abstract}
High-quality RNA is an important genetic study as it has minimal contaminants that can affect gene discovery including degraded RNAs, chemical, and biological residues. Hence, it is a prerequisite for genetic analysis using Next Generation Sequencing (NGS) for accurate and reliable data mining. Despite its importance, extracting high-quality RNA from different samples is often a challenge, as every tissue has a different biochemical composition, thus requiring different protocols. This paper reports protocols for the extraction of high-quality RNA from two type of pineapple tissues, which are thickly lignified hard tissue (tillers, inflorescence, flowers) and watery soft tissue (mature fruit, ripe fruit, and overripe fruit) via modified Kim and Hamada (2005) method. Total RNA was extracted in all six tissues, which showed two distinctive $25 \mathrm{~S}$ and $18 \mathrm{~S}$ band on agarose gel. The total RNA in this study was considered high-quality as the minimum concentration was $50 \mathrm{ng} / \mu \mathrm{l}$, the absorbance ratio $\left(\mathrm{A}_{260}: \mathrm{A}_{280}\right)$ was more than 1.8 and RNA integrity number

ARTICLE INFO

\section{Article history:}

Received: 9 November 2020

Accepted: 29 January 2021

Published: 28 May 2021

DOI: https://doi.org/10.47836/pjtas.44.2.03

(RIN) was greater than 7. The obtained results showed that the modified Kim and Hamada (2005) method was effective in extracting high-quality RNA from the challenging MD2 pineapple tissue, which is suitable for subsequent molecular analysis, including the highly sensitive NGS.
\end{abstract}

\section{E-mail addresses:}

kahiru11995@yahoo.com (Khairul Nizam Sehat)

vijay@ums.edu.my (S. Vijay Kumar)

hydayaty@ums.edu.my (Noor Hydayaty Md Yusuf)

*Corresponding author
Keywords: MD2 pineapple, Next Generation Sequencing, RIN number, RNA extraction 


\section{INTRODUCTION}

Next-Generation Sequencing (NGS) is one of the most utilised platforms providing reliable large-scale data within a short time. It facilitates the research of various plant mechanisms and system (Godden et al., 2012; Soltis et al., 2013). Indeed, numerous molecules including DNA, mRNA, small RNA, degraded RNA, long non-coding RNA, exons, and DNA fragments are now being sequenced using various NGS platforms. In the highly sensitive RNAsequencing or transcriptomic analysis, the quality of the data obtained from these NGS platforms ultimately depends on the quality of the starting materials. However, obtaining high-quality RNA from plants that meets requirement for RNA-sequencing remains a challenge.

Many studies have demonstrated the successful isolation of total RNA from biological samples including human, animal, plant, bacteria, fungus, and viruses (Cox, 1968; Holmes et al., 2014; Kałużna et al., 2016). RNA extraction is the process of isolating purified total RNA from the living source samples with minimal degradation and contamination. However, no standardized protocol can be used due to the different composition of various samples that demand different extraction protocols, especially in high secondary metabolite samples as phenolic compounds readily oxidized to form quinones which bind to nucleic acids, preventing extraction of high-quality RNA (Ghangal et al., 2009). Therefore, the extraction protocol should be modified depending on the sample for the extraction of high-quality RNA (Atshan et al., 2012; D. Li et al., 2009; Liu et al., 2018).

Pineapple (Ananas comosus) is an important commercial fruit (Hossain et al., 2015), as well as a model organism for nonclimacteric ripening, rich in polysaccharides, polyphenols, water content, lignin, and fibre (Liu et al., 2018). This study reports a protocol suitable for the extraction of highquality RNA from six pineapple tissues including the tiller, inflorescent, flower, mature fruit, ripe fruit, and overripe fruit. The protocol was modified from Kim and Hamada (2005), which reported DNA and RNA extraction method in sweet potato. The method was equipped to extract total RNA from several tissues of MD2 pineapple which was unsuccessful perhaps due to different tissue composition, resulting in few modifications to obtain high-quality RNA suitable for RNA-based analyses using various platforms utilising NGS technology. Total RNA can be deemed as high-quality if it fits the minimum criteria of NGS requirement which are (a) minimum concentration of $50 \mathrm{ng} / \mu \mathrm{l}$, (b) absorbance ratio $\left(\mathrm{A}_{260}: \mathrm{A}_{280}\right)$ of more than 1.8 , and (c) RNA integrity number (RIN) value greater than 7. In addition, total RNA of high quality can be used for different analytical techniques, including reverse transcription polymerase chain reaction (RT-PCR), realtime fluorescent quantitation polymerase chain reaction (qPCR), and microarray analysis (Ma et al., 2015). 


\section{MATERIALS AND METHODS}

\section{Plant Materials and Apparatus}

\section{Treatment}

Six MD2 pineapple tissues were used in this study and three of them were hard tissues collected from the tiller, inflorescence, and flower, while the other three were soft tissues collected from mature fruit (fruit at ripening index 1), ripe fruit (fruit at ripening index 4), and overripe fruit (fruit at ripening index 7). The level of maturity of the fruits are measured based on the colour of the skin of the pineapple (Bakar et al., 2013). The samples were collected as per Sabah Department of Agriculture guidance at a farm located in Kampong Poring, Inanam, Sabah, Malaysia, in which the tissues were transported in clean plastic bag. Upon arrival, each tissue was rinsed using sterile distilled water and cut into smaller pieces before placing inside clean sterile plastic. The tissues were then stored at $-80^{\circ} \mathrm{C}$ before extraction. RNAse pre-treatment of apparatus and plastic ware was also done by dipping in diethyl pyrocarbonate (DEPC) solution overnight, before sterilizing via autoclave.

\section{Extraction of Total RNA from Hard and} Soft Tissue

Hard Tissues (Tillers, Inflorescence, and Flowers). Total RNA from hard tissues including tillers, inflorescence, and flowers was extracted using a protocol modified from Kim and Hamada (2005). RNA was extracted from approximately $3 \mathrm{~g}$ of the frozen sample which was powdered using a chilled mortar and pestle. The samples were transferred into a fresh tube containing $3 \mathrm{~mL}$ of lysis buffer consisting of $1.4 \mathrm{M} \mathrm{NaCl}$, $20 \mathrm{mM}$ EDTA, $100 \mathrm{mM}$ Tris ( $\mathrm{pH} 8.0$ ), 2\% CTAB, and $2 \% \beta$-mercaptoethanol, then half volume $(\mathrm{v} / \mathrm{v})$ of $6 \mathrm{M}$ sodium chloride (saturated $\mathrm{NaCl}$ ) was added and incubated at $65^{\circ} \mathrm{C}$ for 10 minutes. The samples were centrifuged at $16,600 \times \mathrm{g}$ for 12 minutes at $4{ }^{\circ} \mathrm{C}$ to collect the supernatants, which were then mixed with an equal volume of phenol: chloroform: isoamyl alcohol (125:24:1; $\mathrm{pH} 4.5)$. The samples were centrifuged again at $16,600 \times \mathrm{g}$ for 12 minutes at $4{ }^{\circ} \mathrm{C}$ to collect the uppermost aqueous layer, which was transferred into a fresh tube before adding an equal volume of chloroform: isoamyl alcohol (24:1) and centrifuged at $16,600 \mathrm{x} g$ for 12 minutes at $4^{\circ} \mathrm{C}$. The uppermost aqueous layer was again collected, mixed with an equal volume of absolute ethanol and incubated overnight at $-20^{\circ} \mathrm{C}$. The RNA precipitate was centrifuged at $16,600 \mathrm{x} g$ for 12 minutes at $4^{\circ} \mathrm{C}$, the supernatant was discarded, and the RNA pellet obtained was washed twice with $70 \%$ ethanol. The RNA pellet was air-dried in a vacuum concentrator before resuspension in $30 \mu \mathrm{L}$ DEPC-treated water.

\section{Soft Tissues (Mature, Ripe, and Overripe} Fruits). For the extraction of total RNA from soft tissues including mature, ripe, and overripe fruits, the same protocol for the extraction of hard tissues was used with minor modifications. First, 
the extraction was performed using an extraction buffer containing $400 \mathrm{mM} \mathrm{NaCl}$, $20 \mathrm{mM}$ EDTA, $10 \mathrm{mM}$ Tris-HCl, 1\% SDS, and $2 \% \beta$-mercaptoethanol. Secondly, the soft tissue samples were not incubated at $65^{\circ} \mathrm{C}$ for 10 minutes.

\section{Modification from Kim and Hamada Protocol}

The pineapple tissues were extracted using a protocol modified from Kim and Hamada (2005), from now on referred to as the $\mathrm{KH}$ protocol. The five major procedures performed for the extraction of soft and hard tissues of pineapple are as follows:

a. The initial buffer in the $\mathrm{KH}$ protocol contained $1.4 \mathrm{M} \mathrm{NaCl}, 20 \mathrm{mM}$ EDTA, 0.1 $\mathrm{M}$ Tris/ $\mathrm{HCl}$ (pH 9.5), 2\% CTAB, and 1\% $\beta$-mercaptoethanol. This was modified to contain 2\% $\beta$-mercaptoethanol and Tris/ $\mathrm{HCl}$ was replaced with Tris ( $\mathrm{pH}$ 8.0) for the extraction of hard tissues and soft tissues, and $2 \%$ CTAB was replaced with $1 \%$ SDS for extraction of soft tissues.

b. Instead of adding saturated $\mathrm{LiCl}$ $(10 \mathrm{M})$ after the addition of the lysis buffer in the $\mathrm{KH}$ protocol, saturated $\mathrm{NaCl}(6 \mathrm{M})$ was added for the extraction of hard and soft tissues.

c. The incubation step at $65^{\circ} \mathrm{C}$ for 10 minutes was omitted for the extraction of soft tissue samples.

d. The KH protocol involved two extractions using a C:I (24:1) mixture, in this study, the first extraction was performed using P:C:I (25:24:1), while C:I (24:1) was used for the second extraction of hard and soft tissues.

e. The RNA samples of the pineapple tissues were precipitated with absolute ethanol rather than $\mathrm{LiCl}(10 \mathrm{M})$ in this study.

\section{RNA Concentration, Purity, and Integrity Analyses}

Total RNA for each sample was visualised by $1.2 \%$ agarose gel electrophoresis with $1 \mathrm{X}$ TAE buffer. The total RNA concentration and purity (absorbance $\mathrm{A}_{260}: \mathrm{A}_{280}$ ) were quantified using a NanoDrop ${ }^{\mathrm{TM}}$ Spectrophotometer. The RIN was then calculated using an Agilent 2100 Bioanalyzer system and Agilent RNA 6000 Pico Kit.

\section{RESULTS}

The six pineapple tissues, namely tillers, inflorescent, flower, mature fruit, ripen fruit, and overripe fruit (Figure 1) were first categorised as hard or soft tissues. Hard tissues (tillers, inflorescence, and flowers) typically are composed of a thick lignified wall (Yahia \& Carrillo-López, 2018), while soft tissues (fruit) contain $80 \%$ water (Cordenunsi et al., 2010).

The presence of $25 \mathrm{~S}$ and $18 \mathrm{~S}$ ribosomal RNA (rRNA) was observed in the RNA extracted from all tissues using the modified protocols (Figure 2) and was consistent for all replicate samples $(n=3)$. The quality of the extracted RNA was verified using an automated gel electrophoresis system, demonstrating a RIN ranging from 6.3 to 9.5, with a total RNA concentration between 
$134.3 \mathrm{ng} / \mu 1$ to $1074.6 \mathrm{ng} / \mu \mathrm{l}$ (Figure 3 ). biological replicate are summarized in The gel images also confirmed the RNA Table 1.

integrity. The concentration, purity ratio

and RIN for each tissue with respective

\section{Table 1}

Concentration, purity ratio and RIN value for each pineapple tissues including biological replicate

\begin{tabular}{lcccc}
\hline Tissue & $\begin{array}{c}\text { Biological } \\
\text { replicate }\end{array}$ & Concentration $(\mathrm{ng} / \mu \mathrm{l})$ & A260/280 & RIN no. \\
\hline Tiller & 1 & 442.6 & 2.01 & 7.7 \\
& 2 & 308.8 & 2.12 & 9.5 \\
Inflorescence & 3 & 338.2 & 2.13 & 7.7 \\
& 1 & 678.6 & 2.05 & 8.2 \\
Flower & 2 & 528.1 & 2.08 & 8.7 \\
& 3 & 673.1 & 2.08 & 7.3 \\
& 1 & 1074.6 & 2.16 & 7.2 \\
Mature fruit & 2 & 709.3 & 2.08 & 7.6 \\
(Fruit at ripening & 3 & 449.8 & 2.08 & 7.2 \\
index 1) & 1 & 309.7 & 2.11 & 7.4 \\
& 2 & 137.7 & 1.87 & 7.2 \\
Ripe fruit & 3 & 533.0 & 2.03 & 7.8 \\
(Fruit at ripening & 1 & 434.5 & 2.01 & 7.8 \\
index 4) & 2 & 134.3 & 2.09 & 7.1 \\
Overripe fruit & 3 & 495.1 & 2.05 & 9.0 \\
(Fruit at ripening & 1 & 243.7 & 1.96 & 7.9 \\
index 7) & 2 & 200.6 & 2.12 & 9.1 \\
& 3 & 205.4 & 2.13 & 8.3 \\
\hline
\end{tabular}




\section{(a)}

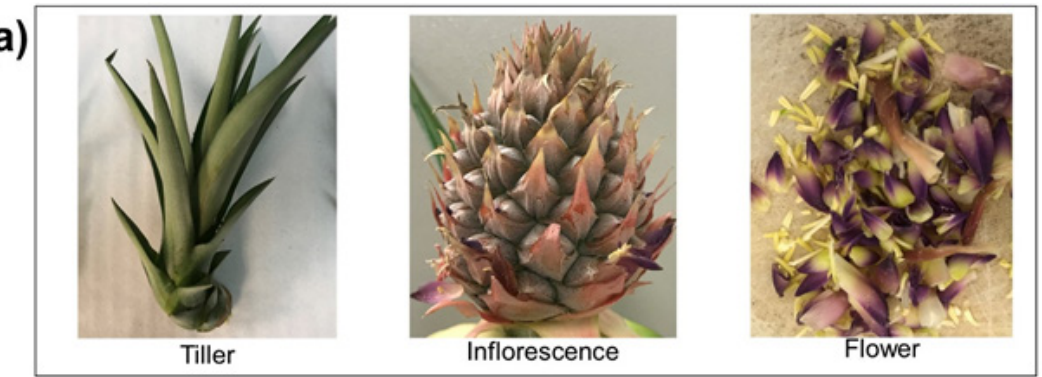

(b)

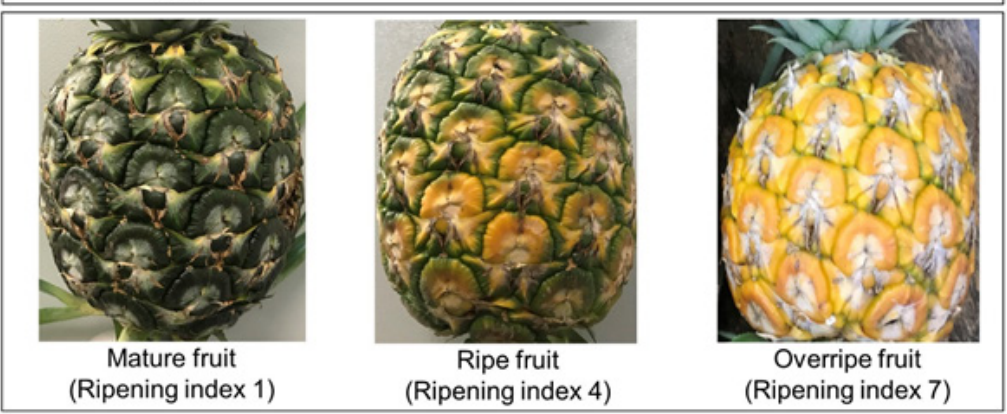

Figure 1. Samples of MD2 pineapple used for RNA extraction. (a) Hard tissue samples of tillers, inflorescence, and flowers; (b) soft tissue samples of mature fruit (at ripening index 1), ripe fruit (at ripening index 4), and overripe fruit (at ripening index 7)

(a)

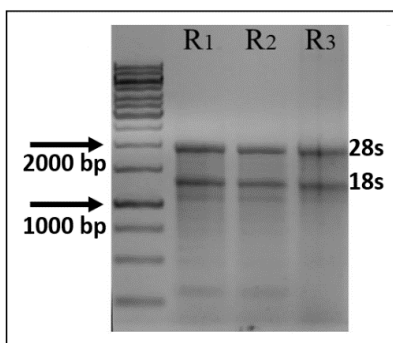

Tiller

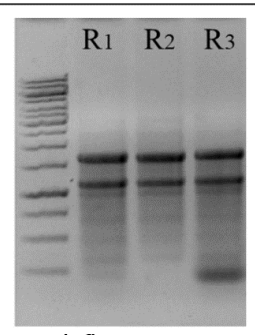

Inflorescence

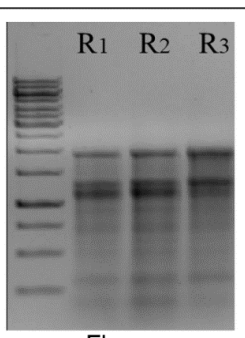

Flower

(b)

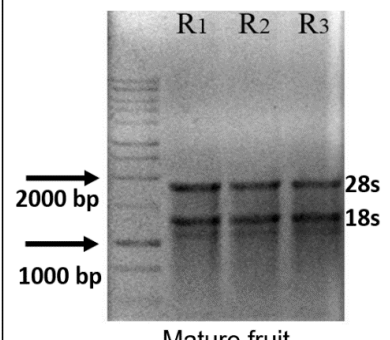

Mature fruit (Ripening index 1)

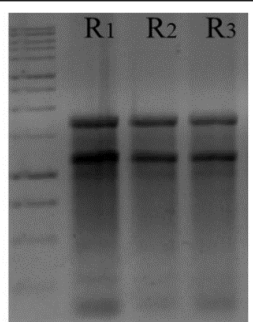

Ripe fruit

(Ripening index 4)

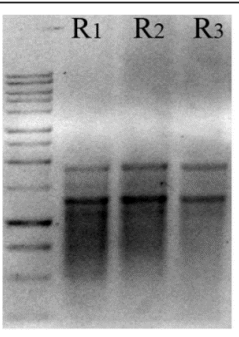

Overripe fruit (Ripening index 7)

Figure 2. Presence of intact $25 \mathrm{~S}$ and $18 \mathrm{~S}$ rRNA in the RNA extracted from pineapple tissues with three biological replicates (R1, R2, and R3), run with ' 0 ' GeneRuler ${ }^{\mathrm{TM}} 1 \mathrm{~kb}$ DNA ladder. (a) Hard tissue samples of tillers, inflorescence, and flowers; (b) soft tissue samples of mature fruit (at ripening index 1), ripe fruit (at ripening index 4), and overripe fruit (at ripening index 7) 


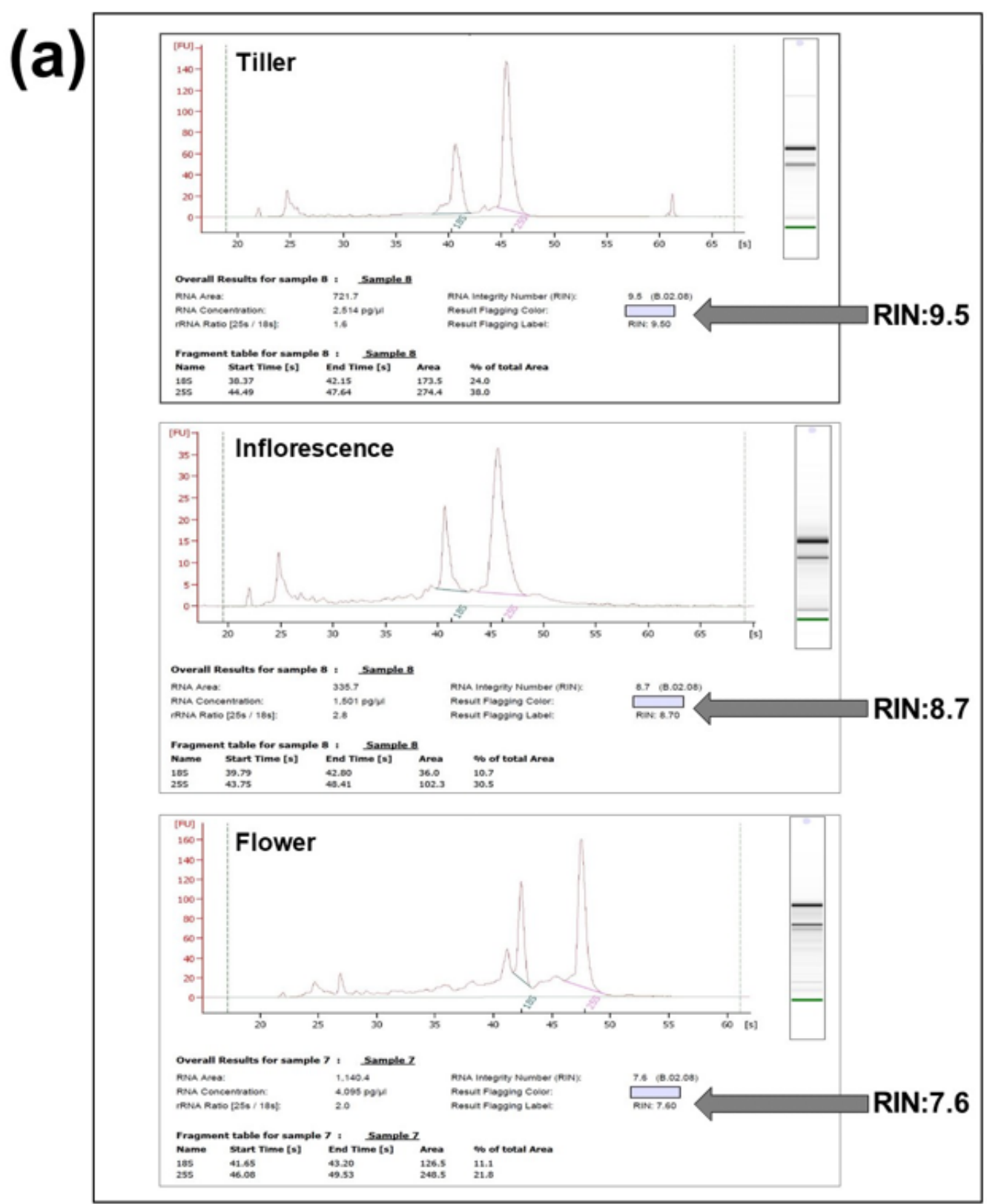

Figure 3. Profile image of intact 25S rRNA, 18S rRNA, and RIN from extracted RNA from (a) Hard tissue samples of tillers, inflorescence, and flowers; (b) soft tissue samples of mature fruit (at ripening index 1), ripe fruit (at ripening index 4), and overripe fruit (at ripening index 7) 


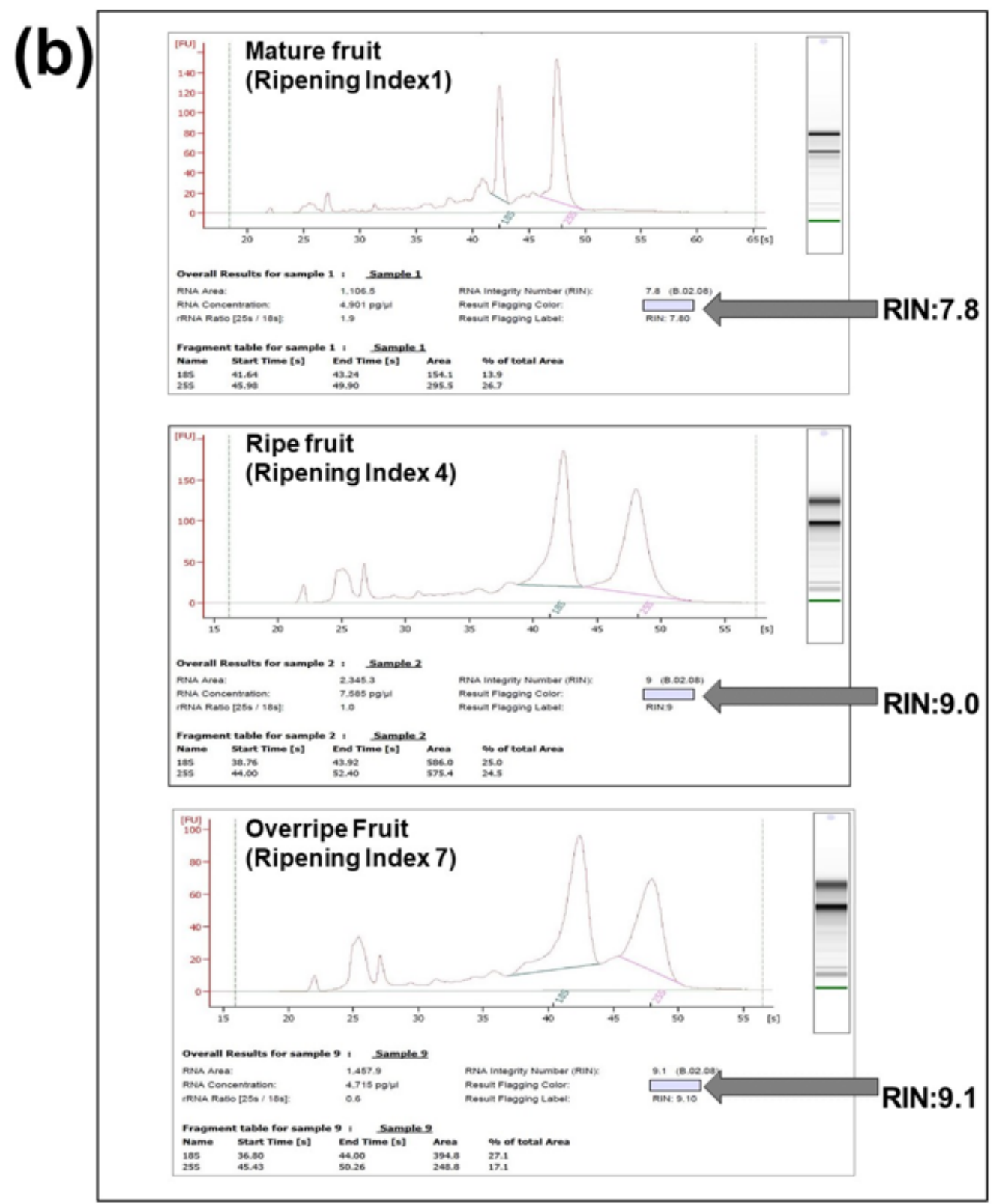

Figure 3. Profile image of intact 25S rRNA, 18S rRNA, and RIN from extracted RNA from (b) soft tissue samples of mature fruit (at ripening index 1), ripe fruit (at ripening index 4), and overripe fruit (at ripening index 7) 


\section{DISCUSSION}

This study reported protocols for the extraction of total RNA from six pineapple tissues, namely hard tissue samples of the tiller, inflorescence, and flower, as well as soft tissue samples of mature fruit (fruit at ripening index 1), ripe fruit (fruit at ripening index 4), and overripe fruit (fruit at ripening index 7). The $\mathrm{KH}$ extraction protocol was first developed to extract RNA from sweet potato (Ipomoea batatas (L). Lam.) tissues including the fibrous roots, tuberous roots, flowers, leaves, stems, petioles, thick pigmented roots, and the mature resting tubers (Kim \& Hamada, 2005). Hence, it was considered suitable for the extraction of RNA from various pineapple tissues.

The protocol was modified to successfully extract high-quality RNA from both hard and soft tissues of pineapple. $\beta$-mercaptoethanol is a strong denaturant commonly used in extraction buffer, with volumes reaching as high as 5\% reported (Wang et al., 2010; White et al., 2008). The $\beta$-mercaptoethanol concentration in the extraction buffer used in this study was increased from $1 \%$ to $2 \%$, thus postulated to increase the rate of RNAse degradation and inhibit its activity, in turn ensuring RNA stability (Azmat et al., 2012; Wang et al., 2010).

Plant tissues contain high levels of polysaccharides, which physiochemically can interact with RNA, thus co-precipitate with RNA, which in turn affects the quality of the RNA. Saturated sodium chloride was used in this study to increase the solubility of polysaccharides, thus reducing the rate of co-precipitation with RNA (Tel-Zur et al., 1999; Wong et al., 2014; X. Li et al., 2011).

The use of CTAB has been reported to be more suitable than SDS for the RNA extraction of samples with leafy-structures including the hard tissues of pineapple (Jordon-Thaden et al., 2015; White et al., 2008; Wong et al., 2014; Yu et al., 2012). As such, CTAB helps to break the thick lignified cell walls of the tissues, separating nucleic acids from polysaccharides (ChaparroEncinas et al., 2020; Jaakola et al. 2001; Jordon-Thaden et al., 2015). The extraction of high-quality RNA using CTAB from soft pineapple tissues was also done but was found to be unsuitable in this study; hence SDS was used to obtain total RNA. The main factor may be due to the tissue compositions as hard tissues are thickly lignified, whereby the soft pineapple tissues have more water content ( $85 \%$ ) and usually are more acidic $(\mathrm{pH} \sim 3.5)$, making the use of SDS more suitable in soft pineapple tissues (Shamsudin et al., 2007). Despite SDS being suitable to extract RNA for soft tissue in this study; however there was no clear correlation between CTAB suitability in hard tissue and SDS in soft tissue as many other protocols have used SDS to extract RNA from hard tissue (Hou et al., 2011; Huded et al., 2018; Ramimoghadam et al., 2012). The incubation at $65^{\circ} \mathrm{C}$ for extraction was suitable for all hard tissues as it is postulated to increase the efficiency of cell wall degradation.

Phenol was added to the mixture of chloroform and isoamyl alcohol as it provides several advantages in the 
process of RNA separation from other contaminants including DNA, proteins, lipids, carbohydrates, and cell debris. Generally, the addition of chloroform alone into a solution that contains RNA forms a biphasic emulsion separating contaminants from total RNA, with the upper layer of the emulsion (the hydrophilic layer) containing the nucleic acids, while the lower layer (the hydrophobic layer) contains other contaminants (Tan \& Yiap, 2009). Thus, the use of chloroform alone may not be sufficient to extract RNA without DNA contamination. As such, the acidic conditions developed with the addition of phenol causes the RNA to remain in the upper layer, with most DNA and proteins remaining in the interphase or lower layer (Chomczynski \& Sacchi, 2006; Maes \& Messens, 1992). Because of this, this study also used acid phenol for separating RNA from contaminants including DNA. On the other hand, the presence of isoamyl alcohol helps to continuously inhibit RNAse activity maintaining RNA stability (Tüzmen et al., 2018). Ethanol is volatile, it is useful in the preparation of samples for NGS purposes, to ensure that the sample is free from chemical residues, as compared to $\mathrm{LiCl}$ (Hopkins et al., 2009).

Based on the modification of Kim and Hamada (2005) method, total RNA was successfully extracted from pineapple tissues of different compositions (soft and hard tissues). Total RNA was present in each tissue as seen on Figure 2 with two distinctive band of $25 \mathrm{~S}$ and $18 \mathrm{~S}$ representing intact total RNA. Further assays via Nanodrop ${ }^{\mathrm{TM}}$
Spectrophotometer (Table 1) and Agilent Bioanalyzer (Figure 3) show total RNA extracted having concentration of more than $50 \mathrm{ng} / \mu 1$, absorbance ratio (A260:A280) of more than 1.8 and RIN value of more than 7, which are deemed acceptable for RNA sequencing via NGS platform (Kukurba \& Montgomery, 2015; Sheng et al., 2017).

\section{CONCLUSION}

High-quality RNA was successfully extracted using modified Kim and Hamada (2005) protocol which can be used on tissue with thick lignified cell wall (hard tissues) as well as high water content tissues (soft tissues) of pineapple. The high-quality total RNA reaching minimum concentration, absorbance ratio, and RIN value are applicable for various analytical techniques like reverse transcription polymerase chain reaction (RT-PCR), real-time fluorescent quantitation polymerase chain reaction (qPCR), microarray analysis, and RNAsequencing via NGS platforms.

\section{ACKNOWLEDGEMENTS}

This research was funded by the Ministry of Higher Education Malaysia, through Fundamental Research Grant Scheme (FRGS), Project code FRG0488-2018.

\section{REFERENCES}

Atshan, S. S., Shamsudin, M. N., Lung, L. T., Ling, K. H., Sekawi, Z., Pei, C. P., \& Ghaznavi-Rad, E. (2012). Improved method for the isolation of RNA from bacteria refractory to disruption, including $S$. aureus producing biofilm. Gene, 494(2), 219-224. https://doi.org/10.1016/j. gene.2011.12.010 
Azmat, M. A., Khan, I. A., Cheema, H. M., Rajwana, I. A., Khan, A. S., \& Khan, A. A. (2012). Extraction of DNA suitable for PCR applications from mature leaves of Mangifera indica L.. Journal of Zhejiang University Science B, 13(4), 239-243. https://doi.org/10.1631/jzus.B1100194

Bakar, B. H., Ishak, A. J., Shamsuddin, R., \& Hassan, W. Z. (2013). Ripeness level classification for pineapple using RGB and HSI colour maps. Journal of Theoretical and Applied Information Technology, 57(3), 587-593.

Chaparro-Encinas, L. A., Arellano-Wattenbarger, G. L., Parra-Cota, F. I., \& Santos-Villalobos, S. (2020). A modified CTAB and Trizol ${ }^{\circledR}$ protocol for high-quality RNA extraction from whole wheat seedlings, including rhizosphere. Cereal Research Communications, 48(3), 275-282. https://doi.org/10.1007/s42976-020-00046-9

Chomczynski, P., \& Sacchi, N. (2006). The single-step method of RNA isolation by acid guanidinium thiocyanate-phenol-chloroform extraction: Twenty-something years on. Nature Protocols, 1(2), 581-585. https://doi.org/10.1038/ nprot. 2006.83

Cordenunsi, B., Saura-Calixto, F., Diaz-Rubio, M. E., Zuleta, A., Tiné, M. A., Buckeridge, M. S., Silva, G. B. D., Carpio, C., Giuntini, E. B., Menezes, E. W. D., \& Lajolo, F. (2010). Carbohydrate composition of ripe pineapple (cv. Perola) and the glycemic response in humans. Food Science and Technology, 30(1), 282-288. https://doi. org/10.1590/S0101-20612010000100041

Cox, R. A. (1968). The use of guanidinium chloride in the isolation of nucleic acids. Methods in Enzymology, 12(Part B), 120-129. https://doi. org/10.1016/0076-6879(67)12123-X

Ghangal, R., Raghuvanshi, S., \& Sharma, P., C. (2009). Isolation of good quality RNA from a medicinal plant seabuckthorn, rich in secondary metabolites. Plant Physiology and Biochemistry, 47(11), 1113-15. https://doi.org/10.1016/j. plaphy.2009.09.004
Godden, G. T., Jordon-Thaden, I. E., Chamala, S., Crowl, A. A., García, N., Germain-Aubrey, C. C., Heaney, J. M., Latvis, M., Qi, X., \& Gitzendanner, M. A. (2012). Making nextgeneration sequencing work for you: Approaches and practical considerations for marker development and phylogenetics. Plant Ecology and Diversity, 5(4), 427-450. https://doi.org/10 $.1080 / 17550874.2012 .745909$

Holmes, A., Birse, L., Jackson, R. W., \& Holden, N. J. (2014). An optimized method for the extraction of bacterial $m$ RNA from plant roots infected with Escherichia coli O157:H7. Frontiers in Microbiology, 5, 286. https://doi.org/10.3389/ fmicb.2014.00286

Hopkins, J. F., Panja, S., McNeil, S. A. N., \& Woodson, S. A., (2009). Effect of salt and RNA structure on annealing and strand displacement by Hfq. Nucleic Acids Research, 37(18), 62056213. https://doi.org/10.1093/nar/gkp646

Hossain, M. F., Akhtar, S., \& Anwar, M. (2015). Nutritional value and medicinal benefits of pineapple. International Journal of Nutrition and Food Sciences, 4(1), 84-88. https://doi. org/10.11648/j.ijnfs.20150401.22

Hou, P., Xie, Z., Zhang, L., Song, Z., Mi, J., He, Y., \& Li, Y. (2011) Comparison of three different methods for total RNA extraction from Fritillaria unibracteata: A rare Chinese medicinal plant. Journal of Medicinal Plants Research, 5(13), 2835-2839. https://doi.org/10.5897/ JMPR.9000389

Huded, A., Jingade, P., \& Mishra, M. K. (2018). A rapid and efficient SDS-based RNA isolation protocol from different tissues of coffee. 3 Biotech, 8(3), 183. https://doi.org/10.1007/ s13205-018-1209-z

Jaakola, L., Pirttilä, A. M., Halonen, M., \& Hohtola, A. (2001). Isolation of high quality RNA from bilberry (Vaccinium myrtillus L.) fruit. Molecular Biotechnology, 19(2), 201-203. https://doi. org/10.1385/MB:19:2:201 
Jordon-Thaden, I. E., Chanderbali, A. S., Gitzendanner, M. A., \& Soltis, D. E. (2015). Modified CTAB and TRIzol protocols improve RNA extraction from chemically complex Embryophyta. Applications in Plant Sciences, 3(5), 1400105. https://doi.org/10.3732/apps.1400105

Kałużna, M., Kuras, A., Mikiciński, A., \& Puławska, J. (2016). Evaluation of different RNA extraction methods for high-quality total RNA and mRNA from Erwinia amylovora in planta. European Journal of Plant Pathology, 146(4), 893-899. https://doi.org/10.1007/s10658-016-0967-x

Kim, S. H., \& Hamada, T. (2005). Rapid and reliable method of extracting DNA and RNA from sweetpotato, Ipomoea batatas (L). Lam. Biotechnology Letters, 27(23), 1841-1845. https://doi.org/10.1007/s10529-005-3891-2

Kukurba, K. R., \& Montgomery, S. B. (2015). RNA sequencing and analysis. Cold Spring Harbor Protocols, 2015(11), 951-969. https://doi. org/10.1101/pdb.top084970

Li, D., Ren, W., Wang, X., Wang, F., Gao, Y., Ning, Q., Han, Y., Song, T., \& Lu, S. (2009). A modified method using TRIzol ${ }^{\circledR}$ reagent and Liquid nitrogen produces high-quality RNA from rat pancreas. Applied Biochemistry and Biotechnology, 158(2), 253-61. https://doi. org/10.1007/s12010-008-8391-0

Li, X., Wang, C., Sun, H., \& Li, T. (2011). Establishment of the total RNA extraction system for lily bulbs with abundant polysaccharides. African Journal of Biotechnology, 10(78), 17907-17915. https:// doi.org/10.5897/AJB10.2523

Liu, L., Han, R., Yu, N., Zhang, W., Xing, L., Xie, D., \& Peng, D. (2018). A method for extracting high-quality total RNA from plant rich in polysaccharides and polyphenols using Dendrobium huoshanense. PLOS One, 13(5), 1-9. https://doi.org/10.1371/journal. pone. 0196592
Ma, Z., Huang, B., Xu, S., Chen, Y., Li, S., \& Lin, S. (2015) Isolation of high-quality total RNA from Chinese Fir (Cunninghamia lanceolata (Lamb.) Hook). PLOS One, 10(6), e0130234. https://doi. org/10.1371/journal.pone.0130234

Maes, M., \& Messens, E. (1992). Phenol as grinding material in RNA preparations. Nucleic Acids Research, 20(16), 4374. https://doi.org/10.1093/ nar/20.16.4374

Ramimoghadam, D., Hussein, M. Z., \& Taufiq-Yap, Y. H. (2012). The effect of sodium dodecyl sulfate (SDS) and cetyltrimethylammonium bromide (CTAB) on the properties of $\mathrm{ZnO}$ synthesized by hydrothermal method. International Journal of Molecular Science, 13(10), 13275-13293. https:// doi.org/10.3390/ijms131013275

Shamsudin, R., Daud, W., Takriff, M., \& Hassan, O. (2007). Physicochemical properties of the Josapine variety of pineapple fruit. International Journal of Food Engineering, 3(5), 14. https:// doi.org/10.2202/1556-3758.1115

Sheng, Q., Vickers, K., Zhao, S., Wang, J., Samuels, D. C., Koues, O., Shyr, Y., \& Guo, Y. (2017). Multi-perspective quality control of Illumina RNA sequencing data analysis. Briefings in Functional Genomics, 16(4), 194-204. https:// doi.org/10.1093/bfgp/elw035

Soltis, D. E., Gitzendanner, M. A., Stull, G., Chester, M., Chanderbali, A., Chamala, S., Jordan-Thaden, I., Soltis, P. S., Schnable, P. S., \& Barbazuk, W. B. (2013). The potential of genomics in plant systematic. Taxon, 62(5), 886898. https://doi.org/10.12705/625.13

Tan, S. C., \& Yiap, B. C. (2009). DNA, RNA, and protein extraction: The past and the present. Journal of Biomedicine and Biotechnology, 2009, 574398. https://doi.org/10.1155/2009/574398

Tel-zur, N., Abbo, S., Myslabodski, D., \& Mizrahi, Y. (1999). Modified CTAB procedure for DNA isolation from epiphytic cacti of the genera Hylocereus and Selenicereus (Cactaceae). Plant 
Molecular Biology Reporter, 17(3), 249-254. https://oi.org/10.1023/A:1007656315275

Tüzmen, S., Baskin, Y., Nursal, A. F., Eraslan, S., Esemen, Y., Çalibas, G., Demir, A. B., Abbasoglu, D., \& Hizel, C. (2018). Techniques for nucleic acid engineering: The foundation of gene manipulation. In D. Barh \& V. Azevedo (Eds.), Omics technologies and bio-engineering: Towards improving quality of life (pp. 247-315). Academic Press. https://doi.org/10.1016/B9780-12-804659-3.00014-2

Wang, X. X., Wang, B., Liu, L. J., Cui, X. P., Yang, J. Y., Wang, H., Jiang, H., Luo, B. B., Long, Z., Dou, W. X., Zhang, N., \& Peng, D. X. (2010). Isolation of high-quality RNA and construction of a suppression subtractive hybridization library from ramie (Boehmeria nivea L. Gaud.). Molecular Biology Reports, 37(4), 2099-2103. https://doi.org/10.1007/s11033-009-9671-7

White, E. J., Venter, M., Hiten, N. F., \& Burger, J. T. (2008). Modified cetyltrimethylammonium bromide method improves robustness and versatility: The benchmark for plant RNA extraction. Biotechnology Journal, 3(11), 14241428. https://doi.org/10.1002/biot.200800207
Wong, L. M., Silvaraj, S., \& Phoon, L. Q., (2014). An optimised high-salt CTAB protocol for both DNA and RNA isolation from succulent stems of Hylocereus sp.. Journal of Medical Bioengineering, 3(4), 236-240. https://doi. org/10.12720/jomb.3.4.236-240

Yahia, E., \& Carrillo-López, A. (Eds.) (2018). Postharvest physiology and biochemistry of fruits and vegetables $\left(1^{\text {st }} \mathrm{ed}\right.$.). Woodhead Publishing.

Yu, D., Tang, H., Zhang, Y., Du, Z., Yu, H., \& Chen, Q. (2012). Comparison and improvement of different methods of RNA isolation from strawberry (Fragria $\times$ ananassa). Journal of Agricultural Science, 4(7), 51-56. https://doi. org/10.5539/jas.v4n7p51 
